\title{
Analyzing size-symmetric vs. size-asymmetric and intra- vs. inter-specific competition in beech (Fagus sylvatica L.) mixed stands
}

\author{
Miren del Río ， Sonia Condés , Hans Pretzsch
}

\begin{abstract}
A B S T R A C T
In mixed stands, inter-specific competition can be lower than intra-specific competition when niche complementarity and/or facilitation between species prevail. These positive interactions can take place at belowground and/or aboveground levels. Belowground competition tends to be size symmetric while the aboveground competition is usually for light and almost always size-asymmetric. Interactions between forest tree species can be explored analyzing growth at tree level by comparing intra and inter-specific competition. At the same time, possible causes of niche complementarity can be inferred relating intra and inter-specific competition with the mode of competition, i.e. size-symmetric or sizeasymmetric. The aim of this paper is to further our understanding of the interactions between species and to detect possible causes of competition reduction in mixed stands of beech (Fagus sylvatica L.) with other species: pine-beech, oak-beech and fir-beech. To test whether species growth is better explained by size-symmetric and/or size-asymmetric competition, five different competition structures where included in basal area growth models fitted using data from the Spanish National Forest Inventory for the Pyrenees. These models considered either size-symmetry only (Reineke's stand density index, SDI), size-asymmetry only (SDI of large trees or SDI of small trees), or both combined. In order to assess the influence of the admixture, these indices were introduced in two different ways, one of which was to consider that trees of all species compete in a similar way, and the other was to split the stand density indices into intra- and inter-specific competition components. The results showed that in pine-beech mixtures, there is a slightly negative effect of beech on pine basal area growth while beech benefitted from the admixture of Scots pine; this positive effect being greater as the proportion of pine trees in larger size classes increases. In oak-beech mixtures, beech growth was also positively influenced by the presence of oaks that were larger than the beech trees. The growth of oak, however, decreased when the proportion of beech in SDI increased, although the presence of beech in larger size classes promoted oak growth. Finally, in fir-beech mixtures, neither fir nor beech basal area growth were influenced by the presence of the other species. The results indicate that size-asymmetric is stronger than size-symmetric competition in these mixtures, highlighting the importance of light in competition. Positive species interactions in size-asymmetric competition involved a reduction of asymmetry in tree size-growth relationships.
\end{abstract}

\section{Introduction}

Overyielding due to a positive mixing effect is often found when comparing growth in pure and mixed stands. Higher productivity in mixed stands may occur when niche complementarity and/or facilitation between cohabiting species exists. One way to reveal interactions between forest species is to analyze growth at tree level by comparing intra and inter-specific competition, which is generally explored through competition indices (e.g. Canham et al., 2004; Pretzsch and Schütze, 2009; Perot et al., 2010). Interspecific competition in mixed stands may be lower than intra-specific competition when there is a strong niche complementarity between the species and/or facilitation. In contrast, inter-specific 
competition may be greater when interaction between species due to niche similarity and/or allelopathic impediment prevails. Positive interactions at tree level might involve overyielding at stand level, although results at tree level cannot always be directly extrapolated to stand level (Perot and Picard, 2012).

Positive interactions can take place at aboveground and/or belowground levels and at different functional characteristics. One way to identify possible causes of niche complementarity is to study intra and inter-specific competition in relation to the mode of competition; size-symmetric or size-asymmetric. Completely size symmetric competition or two-sided competition occurs where resource uptake among competitors is independent of their relative sizes, and completely size-asymmetric competition or one-sided competition occurs where the largest plants obtain all the contested resources (Schwinning and Weiner, 1998). Although there is not a general relationship between the degree of size symmetry or asymmetry and the particular growth limiting resources, many studies (Weiner et al., 1990; Wichmann, 2001) pointed to an association between size-symmetric competition and competition for below-ground resources on the one hand, and between sizeasymmetric competition and above-ground competition for light on the other.

Growth models usually quantify size-symmetric or asymmetric competition by competition indices. When competition indices consider only one-side competition, i.e. only trees larger than the target tree are considered as competitors, they express a size-asymmetric mode of competition. If they include all trees as competitors they can express all modes from size-symmetric to size-asymmetric competition depending on the competition index formulation (Weiskittel et al., 2011).

Beech stands (Fagus sylvatica L.) mixed with other forest species frequently exhibit higher growth rates than corresponding pure beech stands (Milios, 2004; Pretzsch and Schütze, 2009; Pretzsch et al., 2010, 2013; Condés et al., 2013), although this positive effect of mixing was found to depend on stand density (Condés et al., 2013; Río et al., 2013), site conditions (Pretzsch et al., 2010, 2013) and temporal variations in growing conditions (Río et al., 2014). This species presents a low self-tolerance, which implies high intra-specific competition (Pretzsch and Biber, 2005) and an improvement in growth through the admixture with most other species. Overyielding in mixed beech forests has been attributed to a number of different factors such as differences in space occupation efficiency (Pretzsch and Schütze, 2009), and root systems (Leuschner et al., 2001) although they varied depending on the mixture.

In this study we explore size-symmetric and size-asymmetric competition in mixed beech stands to gain a clearer understanding of the interactions between species and to determine possible causes of competition reduction in pine-beech, oak-beech and fir-beech mixtures. As a surrogate of size-symmetric competition we used the stand density index proposed by Reineke, estimated as the sum of stand density index by species, while to express size-asymmetric competition we used the same index, but calculated only for trees larger than the target tree (SDIL). We estimated these indices for trees of the two species together, but also split them into intra- and inter-specific components. Through these indices we explore the following questions:

(i) Is competition in these mixtures mainly size-symmetric or size-asymmetric?

(ii) Are the mixing effects more associated with size-symmetric or with size-asymmetric competition?

(iii) How do intra and inter-specific competition vary among the studied mixtures?

\section{Materials and methods}

\subsection{Data}

To explore species interactions we selected mixed-beech stands in the Pyrenees, in North-West Spain, (UTM zone 30N, X 565,000980,$000 ;$ Y 4,650,000-4,794,000). Data were obtained from 177 sample plots belonging to the Spanish National Forest Inventories (SNFI). Plots located in the main mixtures of F. sylvatica in the Pyrenees were selected: 100 sample plots mixed with Pinus sylvestris L., 48 sample plots with Quercus petraea (Matts.) Liebl. and 29 sample plots with Abies alba Mill. As the aim was to compare the different intra and inter-specific competition for each species at tree level, the criterion for selecting mixed plots was the presence of both species, regardless of the proportion of each. Plots where silvicultural treatments were applied in the period between inventories were excluded from the selection because the year in which the intervention was performed is not recorded in the SNFI.

All the plots from the SNFI are permanent and have been remeasured over a 10 year period. SNFI plots are located at the nodes of a one kilometer square grid and consist of four concentric sampling circles with radii of 5, 10,15 and $25 \mathrm{~m}$. Within each of these circles, the diameters and heights of all trees are recorded according to dbh class (over $7.5,12.5,22.5$ and $42.5 \mathrm{~cm}$ respectively). The main stand variables (both total and per species) were estimated from individual tree data, weighted according to the area of the concentric subplots (Table 1). A description of the individual tree data at the beginning of the studied growth period for different species along with the stand composition are shown in Table 2.

\subsection{Size-symmetric and size-asymmetric competition}

Although the SNFI data include tree position (distance and azimuth), it was not possible to estimate distance dependent competition indices since not all trees were measured in the whole plot (radius $25 \mathrm{~m}$ ). Therefore, a distance independent approach was used to model individual tree basal area growth for each species and composition. As the main objective of this study was to analyze size-symmetric and size-asymmetric competition in mixed stands, we applied the following indices: size-symmetric competition was expressed by the stand density index (SDI) (Reineke, 1933), and size-asymmetric competition by the stand density index of trees larger than the target tree (SDIL) (Pretzsch and Biber, 2010). SDI is an expression of relative stand density and it characterizes the degree of crowding with reference to standard conditions. Hence, it excludes the normal change in absolute density with increasing stand development. SDIL was derived from the combination of the concepts of SDI and basal area of larger trees (BAL) (Wykoff, 1990), frequently used in growth models to express size-symmetric or size-asymmetric competition respectively (Weiskittel et al., 2011). In addition to SDIL, the complementary stand density index of trees smaller than the target trees (SDIS) was also calculated as a size-asymmetric index to reveal to what extent smaller trees compete for resources. Indices based on the stand density index concept (SDI, SDIL or SDIS) were selected instead of those based on basal area (BA, BAL) because the latter is more influenced by stand development and environmental conditions. Bearing in mind the lack of age data as well as site quality data in the SNFI, the stand density index might be more suitable to express competition in tree growth modeling.

SDI, SDIL and SDIS were calculated for each species according to:

$\mathrm{SDI}=N\left(\frac{25}{d g}\right)^{E}$ 
Table 1

Total and by species stand variables in selected plots.

\begin{tabular}{|c|c|c|c|c|c|c|c|c|c|c|c|c|c|c|c|c|c|}
\hline & & \multicolumn{5}{|c|}{$N\left(\mathrm{ha}^{-1}\right)$} & \multicolumn{4}{|c|}{$D g(\mathrm{~cm})$} & \multicolumn{4}{|c|}{$\mathrm{Ho}(\mathrm{m})$} & \multicolumn{3}{|c|}{ SDI (stem ha-1) } \\
\hline & & Mean & Desv & Min & Max & Mean & Desv & Min & Max & Mean & Desv & Min & Max & Mean & Desv & Min & $\operatorname{Max}$ \\
\hline \multirow{3}{*}{$\begin{array}{l}\text { P. sylvestris and F. sylvatica } \\
\quad n=100\end{array}$} & Total & 876 & 582 & 41 & 2987 & 22.6 & 10.0 & 11.4 & 78.7 & 17.0 & 5.0 & 8.7 & 31.8 & 594.3 & 276.7 & 154.6 & 1341.1 \\
\hline & Pine & 448 & 479 & 5 & 2394 & 26.9 & 10.0 & 12.6 & 56.4 & 16.1 & 5.1 & 7.5 & 31.8 & 362.5 & 299.1 & 14.2 & 1279.3 \\
\hline & Beech & 426 & 533 & 5 & 2769 & 21.5 & 12.8 & 7.6 & 81.6 & 13.8 & 4.8 & 4.3 & 29.0 & 221.5 & 222.4 & 13.7 & 917.3 \\
\hline \multirow[t]{3}{*}{ Q. petrae and $F$. sylvatica $n=48$} & Total & 544 & 375 & 66 & 1894 & 26.2 & 9.3 & 11.9 & 49.2 & 18.9 & 5.1 & 8.4 & 33.8 & 472.8 & 184.8 & 82.0 & 924.5 \\
\hline & Oak & 94 & 181 & 5 & 902 & 35.5 & 18.8 & 11.9 & 83.4 & 17.1 & 5.4 & 7.0 & 31.7 & 93.8 & 110.1 & 11.9 & 461.4 \\
\hline & Beech & 447 & 341 & 19 & 1862 & 24.0 & 8.0 & 8.9 & 45.0 & 17.8 & 5.5 & 6.5 & 32.9 & 373.1 & 216.5 & 24.5 & 883.0 \\
\hline \multirow[t]{3}{*}{ A. alba and $F$. sylvatica $n=29$} & Total & 564 & 336 & 15 & 1288 & 29.0 & 9.0 & 17.6 & 51.8 & 23.6 & 5.6 & 13.2 & 33.9 & 589.2 & 228.4 & 49.2 & 1026.6 \\
\hline & Fir & 223 & 250 & 5 & 1203 & 35.7 & 18.8 & 12.9 & 77.3 & 20.8 & 8.5 & 6.0 & 35.3 & 260.0 & 220.5 & 12.6 & 862.9 \\
\hline & Beech & 340 & 292 & 10 & 1241 & 26.7 & 9.0 & 14.0 & 47.0 & 20.4 & 6.1 & 9.0 & 33.4 & 316.6 & 228.2 & 16.9 & 855.5 \\
\hline
\end{tabular}

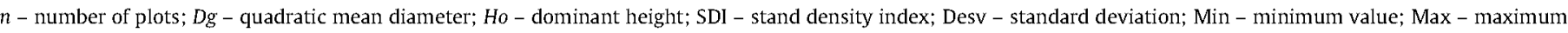
value.

Table 2

Tree characteristics and competition status, total and by species, of the data set.

\begin{tabular}{|c|c|c|c|c|c|c|c|c|c|c|}
\hline & & & $d(\mathrm{~cm})$ & $\begin{array}{l}\text { ig } \\
\left(\mathrm{cm}^{2}\right. \\
\left.\text { year }^{-1}\right)\end{array}$ & $\begin{array}{l}\text { SDlL }_{\text {intra }} \\
\text { (stem } \\
\mathrm{ha}^{-1} \text { ) }\end{array}$ & $\begin{array}{l}\text { SDIL }_{\text {inter }} \\
\text { (stem } \\
\mathrm{ha}^{-1} \text { ) }\end{array}$ & $\begin{array}{l}\text { SDIL } \\
(s t e m \\
h^{-1} \text { ) }\end{array}$ & $\begin{array}{l}\mathrm{SDI}_{\text {intra }} \\
\text { (stem } \\
\mathrm{ha}^{-1} \text { ) }\end{array}$ & $\begin{array}{l}\mathrm{SDI}_{\text {inter }} \\
\text { (stem } \\
\mathrm{ha}^{-1} \text { ) }\end{array}$ & $\begin{array}{l}\text { SDI } \\
(\text { stem } \\
\left.\mathrm{ha}^{-1}\right)\end{array}$ \\
\hline \multirow{8}{*}{$\begin{array}{l}\text { Pinus sylvestris and Fagus } \\
\text { sylvatica }\end{array}$} & \multirow[t]{4}{*}{ Pine $(n=1772)$} & Mean & 28.0 & 13.1 & 274.7 & 26.1 & 302.3 & 591.0 & 130.7 & 735.7 \\
\hline & & Desv & 11.9 & 10.2 & 238.2 & 47.2 & 240.8 & 305.7 & 161.2 & 290.7 \\
\hline & & Mìn & 7.5 & 0.1 & 0.0 & 0.0 & 0.0 & 14.2 & 13.7 & 154.6 \\
\hline & & $\operatorname{Max}$ & 73.8 & 96.3 & 1255.7 & 392.4 & 1255.7 & 1279.3 & 917.3 & 1341.1 \\
\hline & \multirow{4}{*}{$\begin{array}{l}\text { Beech } \\
(n=1047)\end{array}$} & Mean & 23.3 & 11.8 & 188.5 & 171.8 & 364.9 & 429.4 & 215.0 & 658.2 \\
\hline & & Desv & 14.6 & 15.5 & 171.6 & 205.8 & 252.7 & 253.4 & 223.6 & 270.3 \\
\hline & & Min & 7.5 & 0.1 & 0.0 & 0.0 & 0.0 & 13.7 & 14.2 & 154.6 \\
\hline & & Max & 121.0 & 154.5 & 852.1 & 1279.3 & 1294.6 & 917.3 & 1279.3 & 1341.1 \\
\hline \multirow{8}{*}{$\begin{array}{l}\text { Quercus petraea and Fagus } \\
\text { sylvatica }\end{array}$} & \multirow[t]{4}{*}{ Oak $(n=209)$} & Mean & 36.2 & 19.1 & 98.2 & 83.0 & 182.5 & 220.4 & 239.0 & 468.6 \\
\hline & & Desv & 20.4 & 21.3 & 102.3 & 126.7 & 157.8 & 144.7 & 201.9 & 161.2 \\
\hline & & Min & 8.1 & 0.1 & 0.0 & 0.0 & 0.0 & 11.9 & 24.5 & 82.0 \\
\hline & & Max & 100.3 & 147.4 & 436.5 & 621.3 & 796.2 & 461.4 & 883.0 & 924.5 \\
\hline & \multirow[t]{4}{*}{ Beech $(n=898)$} & Mean & 28.3 & 13.1 & 233.4 & 40.5 & 275.8 & 496.3 & 60.9 & 562.2 \\
\hline & & Desv & 12.2 & 13.5 & 172.5 & 56.4 & 179.5 & 181.8 & 72.7 & 166.9 \\
\hline & & Min & 7.6 & 0.1 & 0.0 & 0.0 & 0.0 & 24.5 & 11.9 & 82.0 \\
\hline & & $\operatorname{Max}$ & 80.2 & 102.3 & 857.2 & 461.4 & 890.4 & 883.0 & 461.4 & 924.5 \\
\hline \multirow[t]{8}{*}{ Abies alba and Fagus sylvatica } & \multirow[t]{4}{*}{ Fir $(n=344)$} & Mean & 39.4 & 32.4 & 212.5 & 77.3 & 291.0 & 441.8 & 212.8 & 665.2 \\
\hline & & Desv & 19.7 & 30.9 & 174.8 & 135.5 & 233.0 & 222.5 & 183.9 & 229.3 \\
\hline & & Min & 7.6 & 0.1 & 0.0 & 0.0 & 0.0 & 12.6 & 16.9 & 49.2 \\
\hline & & Max & 122.5 & 143.8 & 833.6 & 724.7 & 976.7 & 862.9 & 855.5 & 1026.6 \\
\hline & \multirow[t]{4}{*}{ Beech $(n=434)$} & Mean & 31.9 & 14.7 & 218.4 & 115.8 & 338.7 & 459.5 & 181.3 & 656.0 \\
\hline & & Desv & 15.7 & 13.4 & 166.9 & 131.8 & 190.8 & 184.3 & 185.6 & 176.2 \\
\hline & & Min & 7.8 & 0.1 & 0.0 & 0.0 & 0.0 & 16.9 & 12.6 & 49.2 \\
\hline & & Max & 112.4 & 89.7 & 796.8 & 703.0 & 921.5 & 855.5 & 862.9 & 1026.6 \\
\hline
\end{tabular}

$n$ - number of trees; desv - standard deviation; min - minimum value; max - maximum value.

$\mathrm{SDIL}=N_{l}\left(\frac{25}{d g_{l}}\right)^{E}$

SDIS $=N_{s}\left(\frac{25}{d g_{s}}\right)^{E}$

where $N$ is the number of stems per hectare; $d g$ is the quadratic mean diameter in centimeters (in both variables including target tree); $E$ is Reineke's maximum stand density exponent; $N_{l}$ and $d g_{l}$ are the number of stems per hectare and quadratic mean diameter of trees larger than the target tree; and $N_{s}$ and $d g_{s}$ are the respective variables of trees smaller than the target tree. Although the speciesspecific values of the coefficient $E$ (Eq. (1)) have previously been determined for the studied species in pure stands (Río et al., 2001; Pretzsch and Biber, 2005), we used the generic figure proposed by Reineke $E=-1.605$ for all species because the value of this exponent has not yet been estimated for species growing in mixture.
To test whether the basal area growth of a given species is better explained by size-symmetric and/or size-asymmetric competition, five different competition structures for inclusion in growth models were explored, considering size-symmetric competition only, size-asymmetric competition only, or a combination of both:

S - only size-symmetric index: SDI.

$A_{L}$ - only size-asymmetric of larger trees index: SDIL.

$A_{S}$ - only size-asymmetric of smaller trees index: SDIS.

$S+A_{L}-$ combining size-symmetric and asymmetric indices: SDI + SDIL.

$A_{L}+A_{S}-$ combining both size-asymmetric indices: SDIL + SDIS

\subsection{Intra and inter-specific competition}

In order to analyze the influence of the admixture on tree growth, two competition structures according to species composition were compared. One of these considers that trees of all species 
compete in a similar way, i.e. intra- and inter-specific competition are assumed to be similar. The other assumes that intra- and interspecific competition may be different. The first structure was expressed through the total density indices, SDI, SDIL or SDIS (calculated including trees of the two species), and the second by splitting the stand density indices into intra- and inter-specific competition components:

$$
\begin{aligned}
& \mathrm{SDI}_{\text {intra }}+\mathrm{SDI}_{\text {inter }} \\
& \mathrm{SDIL}_{\text {intra }}+\mathrm{SDIL}_{\text {inter }} \\
& \text { SDIS }_{\text {intra }}+\mathrm{SDIS}_{\text {inter }}
\end{aligned}
$$

If the inclusion of the total stand density indices in the growth model results in a better fit than the use of the intra- and inter-specific indices, it may indicate similar intra- and inter-specific competition or no mixing effect.

\subsection{Modeling approach}

The dependent variable for the study was the annual basal area growth of individual trees $\left(\mathrm{cm}^{2}\right.$ year $\left.{ }^{-1}\right)$ obtained from measurements in two consecutive inventories. Basal area growth was preferred to diameter growth because the former is less dependent on tree age (Biondi, 1999), which is not recorded in the SNFI.

We considered the hypothesis that the basal area growth of a species depended on its size following the Hugershoff (1936) growth curve:

$i g_{0 i}=a_{0}^{\prime} \cdot e^{a_{1} d_{i}} \cdot d_{i}^{a_{2}}$

where $i g_{0 i}$ is the basal area increment of the tree $i$ with a given diameter at breast height $d_{i}$; and $a_{0}^{\prime}, a_{1}$, and $a_{2}$ the specific parame- ter to be estimated. The two terms of tree diameter represent the ontogeny pattern of tree basal area growth $\left(i_{0 i}\right)$.

We assume that this growth pattern is modified by the competition status of the tree, so a competition factor $C$ was included in Eq. (4) to express tree basal area growth (ig):

$i g_{i}=i g_{0 i} \cdot e^{C}$

To analyze whether species basal area growth is better explained by size-symmetric and/or size-asymmetric competition and whether overall competition or intra- and inter-specific competition separately are more explanatory, we compared the results obtained including the abovementioned competition structures in the competition factor $C$ of model 5 . First, for each species we compared the models with the five size-symmetric/size-asymmetric structures $\left(S, A_{L}, A_{s}, S+A_{L}, A_{L}+A_{s}\right)$ and each one of these with the two composition structures (total, intra + inter), thus giving ten models for each species (see Table 3 ). Then, the best model for each species was selected considering all possible structures, the abovementioned ten structures as well as structures $S+A_{L}$ and $A_{L}+A_{S}$, which included one of the terms calculated from all trees (total) and the other term calculated by species (intra and inter).

To attain normal distribution of the residuals and reduce heteroscedasticity, a natural logarithmic transformation of the original dependent variable was applied, giving the following linear model

$\log \left(\boldsymbol{i g}_{i}\right)=a_{0}+a_{1} \cdot d_{i}+a_{2} \log \left(d_{i}\right)+\sum b_{k} C_{i k}+\varepsilon_{i}$

where $C_{i k}$ are the $k$ different terms of the competition factor $C$ for tree $i$ according to the abovementioned different size-symmetric/

Table 3

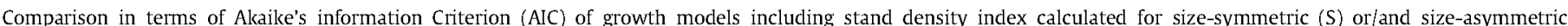

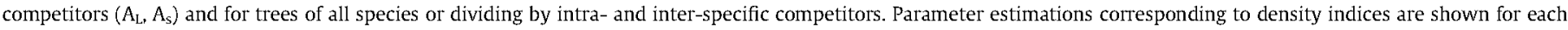

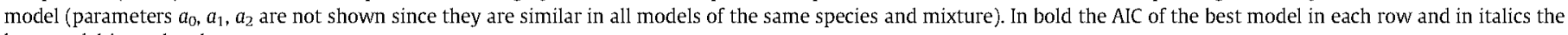
best model in each column.

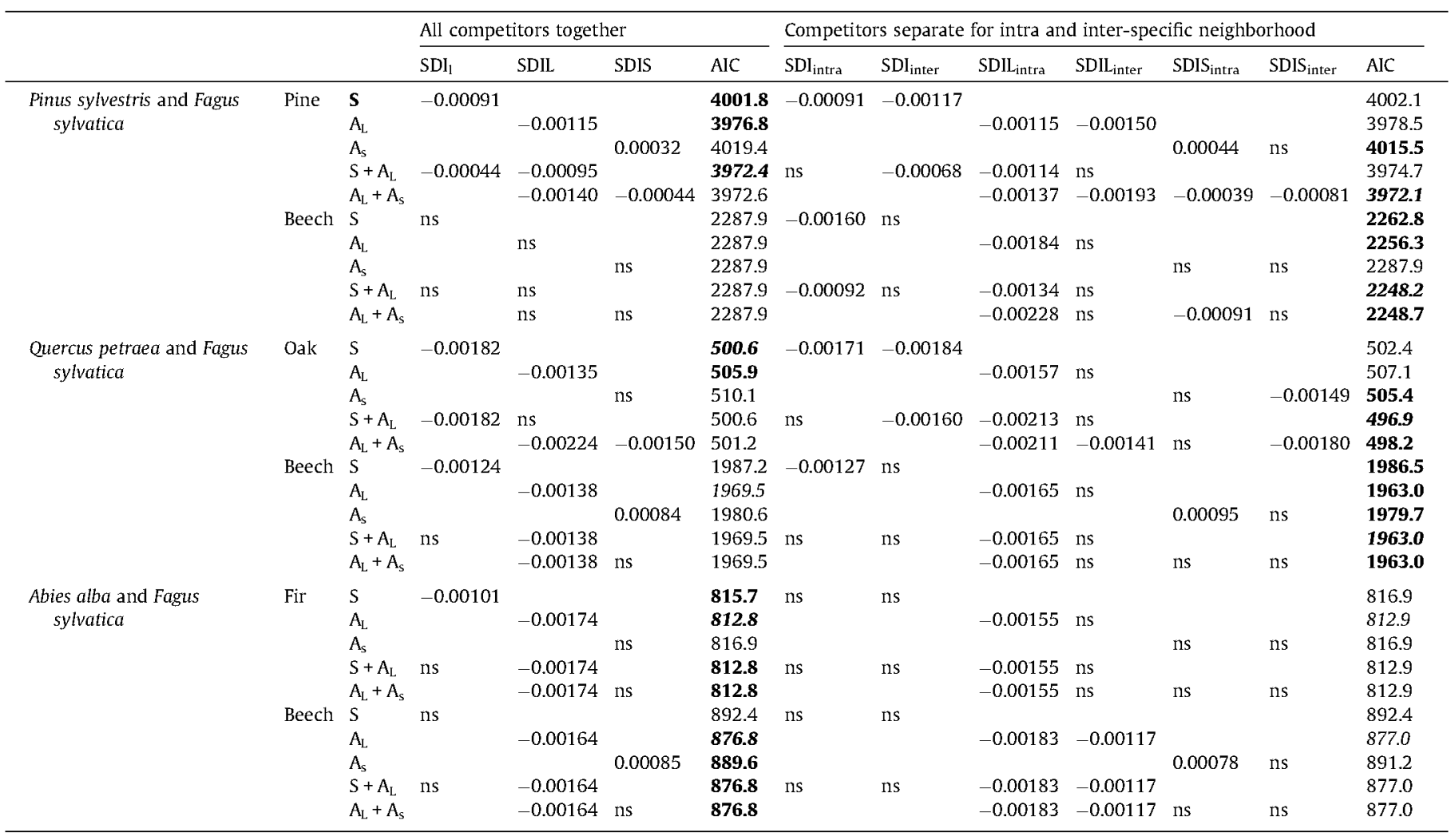


size-asymmetric and composition structures; $b_{k}$ their corresponding parameters to be estimated; and $\varepsilon_{i}$ is the residual term.

Since data came from a hierarchical structure (several trees were measured on the same plot $j$ ) the observations could be correlated. To alleviate this, a mixed model was used, with the plot as the grouping structure of the random effects. We included random effects in both intercept, $a_{0 j}$, and logarithm diameter term, $a_{2 j}$. This inclusion of random effects in the $i g_{0}$ component of the model was expected to explain the variability in tree basal area growth among plots due to growing conditions other than competition (site quality, age, genetic, etc.,). We avoided the inclusion in the model of variables expressing these growth conditions to maintain a constant model structure to allow comparison of results (not always the same variables were statistically significant). The expression of the models is:

$$
\log \left(i g_{i j}\right)=\left(a_{0}+a_{0 j}\right)+a_{1} \cdot d_{i}+\left(a_{2}+a_{2 j}\right) \log \left(d_{i}\right)+\sum b_{k} C_{i k}+\varepsilon_{i j}
$$

To allow the comparison of results we fitted the Eq. (7) by using the ML (maximum likelihood) method of the lme procedure ( $R$, 2011). To compare the models we used the Akaike's information criterium (AIC). A level of $p=0.05$ was used for significance testing of variables in the model. To fit the final best model for each species and mixture the restricted maximum likelihood method (REML) was used.

\section{Results}

The results of the fitted models with size-symmetric competition (model $S$ ), size-asymmetric competition (models $A_{L}$ and $A_{S}$ ), both size-symmetric and size-asymmetric competition (model $S+A_{L}$ ) and both size-asymmetric competition (model $A_{L}+A_{S}$ ) are presented in Table 3 . On the left of the table, the results of models with indices calculated considering all competitors (all species together) are shown, while on the right, the results of models with indices calculated assuming different intra- and inter-specific competitions are given.

\subsection{Size-symmetric and size-asymmetric competition}

In general, when competition was not divided into intra- and inter-specific competitors and when different competition effects were considered independently (models $S, A_{L}$ and $A_{S}$ ), the inclusion of indices expressing the size-asymmetric competition of large trees $\left(A_{L}\right)$ resulted in the best models, with lower AIC values. Conversely, the size-asymmetric competition of smaller trees $\left(A_{s}\right)$ was non-significant or resulted in the worst models. Despite this general result, the basal area growth of the oak growing in beech admixtures was slightly better explained by size-symmetric competition.

When two competition effects were included together in the models, i.e. models $S+A_{L}$ and $A_{L}+A_{s}$, the effect of size-asymmetric competition of larger trees was so strong that the other competition effect remained statistically non- significant for fir and beech in oak and fir admixtures. However, in the case of pine, both sizesymmetric and size-asymmetric terms were statistically significant in model $S+A_{L}$, improving the $A_{l}$ model. For oak, the effect of SDIL was not significant when combined with size-symmetric competition, whereas when the two size-asymmetric competition terms were included together in the model $A_{L}+A_{s}$, both terms were significant. These results revealed the importance of size symmetric competition for oak. For beech growing in pine admixtures, none of the competition terms were statistically significant.

\subsection{Intra and inter-specific competition}

When the differences between intra and inter-specific competition were analyzed, the results showed that in most of the cases, the effect of intra-specific competition was the most important, regardless of whether size-symmetric or size-asymmetric competition was considered.

For beech only the intra-specific competition terms were statistically significant except when growing in fir admixtures, where both intra and inter-specific size-asymmetric competition of large trees were significant. However, this latter model did not improve the model which included all competitors together in SDIL. Similarly, in the case of fir, the model including the total SDIL was slightly better than that which only included intra-specific competitors, SDIL intra.

In the case of pine, both inter and intra-specific effects of competition were significant, the absolute value of parameters being greater for the inter-specific term in the size-symmetric model $\mathrm{S}$ and for the intra-specific term in the size-asymmetric model, $A_{1}$. However, considering two species separately did not improve the models using total indices (SDI and SDIL). An exception was model $A_{s}$, in which just intra-specific SDIS was significant, improving the model where all competitors were considered together. In model $A_{L}+A_{s}$, both intra and inter-specific competition parameters were significant, but the AIC value was only slightly lower than that of the model in which species were not separated.

In the case of oak, the inclusion of intra- and inter-specific size-symmetric competition terms, although both statistically significant, did not improve the results of the total SDI or total SDIL, indicating similar intra- and inter-specific competition. However, the size-asymmetric inter-specific competition of smaller trees explained more growth variability than the total SDIS. The model $S+A_{L}$ showed that the growth variability of oak was better explained by size-symmetric inter-specific competition and by size-asymmetric competition of larger oaks. The result of model $A_{L}+A_{s}$ was similar, showing that the basal area growth of oak was explained by competition with larger oaks and both large and small beech trees.

\subsection{Basal area growth models with best competition structure}

The best models for each species and mixture, when different combinations of competition structures were examined (i.e. allowing each size-symmetric and size-asymmetric term to be calculated either with all trees or splitting into intra- and interspecific competition terms) are shown in Table 4. All models except the pine model showed $R^{2}$ higher than 0.65 when all effects were included and above 0.44 when only fixed effects were considered. The worst fit was obtained for pine, although the $R^{2}$ reached values of 0.49 and 0.33 , including all or only fixed effects respectively.

For most of the species and mixtures, size-asymmetric competition expressed by stand density index of larger trees was the most important effect as regards explaining tree basal area growth variability. However, there were differences between species and admixtures according to the intra and inter-specific competition. For beech growing in pine or oak admixtures and for oak, the best models included the size-asymmetric competition term only for intra-specific competitors, whereas for beech growing with fir, and for pine and fir, the total SDIL resulted in better models. Size-symmetric competition was also significant for pine and oak, and for beech growing in pine admixtures.

In the pine model, the inter-specific size-symmetric competition was greater than the intra-specific competition, while the size-asymmetric competition was similar between species, resulting in a slightly negative effect of beech on pine basal area growth 
Table 4

Parameter estimations and fit statistics for the best growth model for each species and mixture.

\begin{tabular}{|c|c|c|c|c|c|c|c|c|c|c|c|c|c|c|}
\hline & & Intercept & $d$ & $\log (d)$ & $\mathrm{SDI}_{\text {intra }}$ & SDI $I_{\text {inter }}$ & SDI & SDIL $_{\text {intra }}$ & SDIL $_{\text {inter }}$ & SDIL & $\mathrm{AIC}$ & MSE & $R_{\text {all effects }}^{2}$ & $R_{\text {fixed effects }}^{2}$ \\
\hline Beech-pine & $\begin{array}{l}\text { Pine } \\
\text { Beech }\end{array}$ & $\begin{array}{l}-2.8599 \\
-2.6885\end{array}$ & $\begin{array}{l}-0.0441 \\
-0.0247\end{array}$ & $\begin{array}{l}2.1316 \\
1.9203\end{array}$ & $\begin{array}{l}-0.0004 \\
-0.0009\end{array}$ & $\begin{array}{l}-0.0008 \\
\text { ns }\end{array}$ & & -0.0013 & ns & -0.0010 & $\begin{array}{l}4020.6 \\
2282.7\end{array}$ & $\begin{array}{l}0.464 \\
0.361\end{array}$ & $\begin{array}{l}0.491 \\
0.741\end{array}$ & $\begin{array}{l}0.335 \\
0.548\end{array}$ \\
\hline Beech-oak & $\begin{array}{l}\text { Oak } \\
\text { Beech }\end{array}$ & $\begin{array}{l}-3.0627 \\
-3.2677\end{array}$ & $\begin{array}{l}-0.0307 \\
-0.0243\end{array}$ & $\begin{array}{l}2.1158 \\
1.9883\end{array}$ & ns & -0.0016 & & $\begin{array}{l}-0.0021 \\
-0.0016\end{array}$ & $\begin{array}{l}\text { ns } \\
\text { ns }\end{array}$ & & $\begin{array}{l}526.1 \\
1983.2\end{array}$ & $\begin{array}{l}0.442 \\
0.411\end{array}$ & $\begin{array}{l}0.652 \\
0.665\end{array}$ & $\begin{array}{l}0.463 \\
0.448\end{array}$ \\
\hline Beech-fir & $\begin{array}{l}\text { Fir } \\
\text { Beech }\end{array}$ & $\begin{array}{l}-3.0742 \\
-2.6996\end{array}$ & $\begin{array}{l}-0.0441 \\
-0.0264\end{array}$ & $\begin{array}{l}2.3260 \\
1.9038\end{array}$ & & & & & & $\begin{array}{l}-0.0017 \\
-0.0016\end{array}$ & $\begin{array}{l}830.4 \\
898.0\end{array}$ & $\begin{array}{l}0.435 \\
0.369\end{array}$ & $\begin{array}{l}0.729 \\
0.665\end{array}$ & $\begin{array}{l}0.528 \\
0.573\end{array}$ \\
\hline
\end{tabular}

(Fig. 1). Oppositely, beech suffered less competition when there was presence of Scots pine among competitors regardless of the proportion of beech in SDI or in SDIL was. This competitive reduction effect was greater when the proportion of larger pines increased and, consistently, greater for less dominant beech trees (trees with higher SDIL) than for dominant trees (Fig. 2a).

In oak-beech mixture, beech growth was greater for a given SDIL when the presence of oaks in larger trees than the target beech increased (i.e. the $\mathrm{SDIL}_{\text {beech }}$ proportion was low (Fig. 3)), while neither smaller oaks nor smaller beech trees influenced beech growth. Although oak growth decreased as the proportion of beech in SDI increased (higher proportion in the stand), it increased with the presence of beech in competitors of larger size classes, since intra-specific size-asymmetric competition was much stronger than inter-specific competition. As regards the variation of the mixing effect with dominance classes, dominant trees (trees with small SDIL) of both species were less affected than suppressed trees by the presence of large trees of the competing species (Fig. 2a and b).

Finally, in fir-beech models only size-asymmetric competition terms calculated from all trees (total SDIL) were significant. Neither fir nor beech basal area growths were influenced by the presence of the reciprocal species (Fig. 2c).

\section{Discussion}

The present study analyses tree competition in mixed beech forest through growth models and indices which express tree competition status. Our approach does not reveal the underlying biochemical and ecophysiological interactions but provides evidence of mixing effects and suggests possible explanations.

Physiological analyses of species interactions are both costly and complex, which makes them impractical for the study of inter-specific competition at large scales. Moreover, many of the

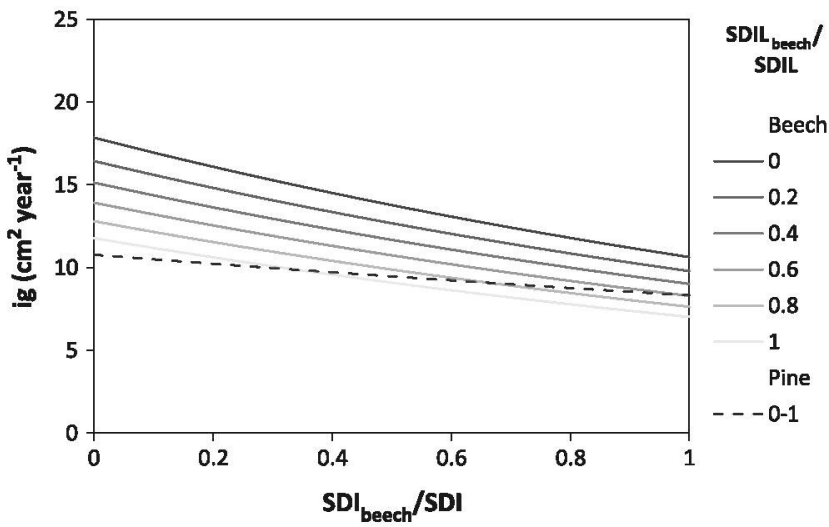

Fig. 1. Beech and pine tree basal area growth according to beech proportion in stand density index $\left(\mathrm{SDI}_{\text {beech }} / \mathrm{SDI}\right)$ and in stand density index of larger trees

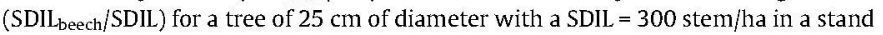
of SDI $=600$ stem/ha.
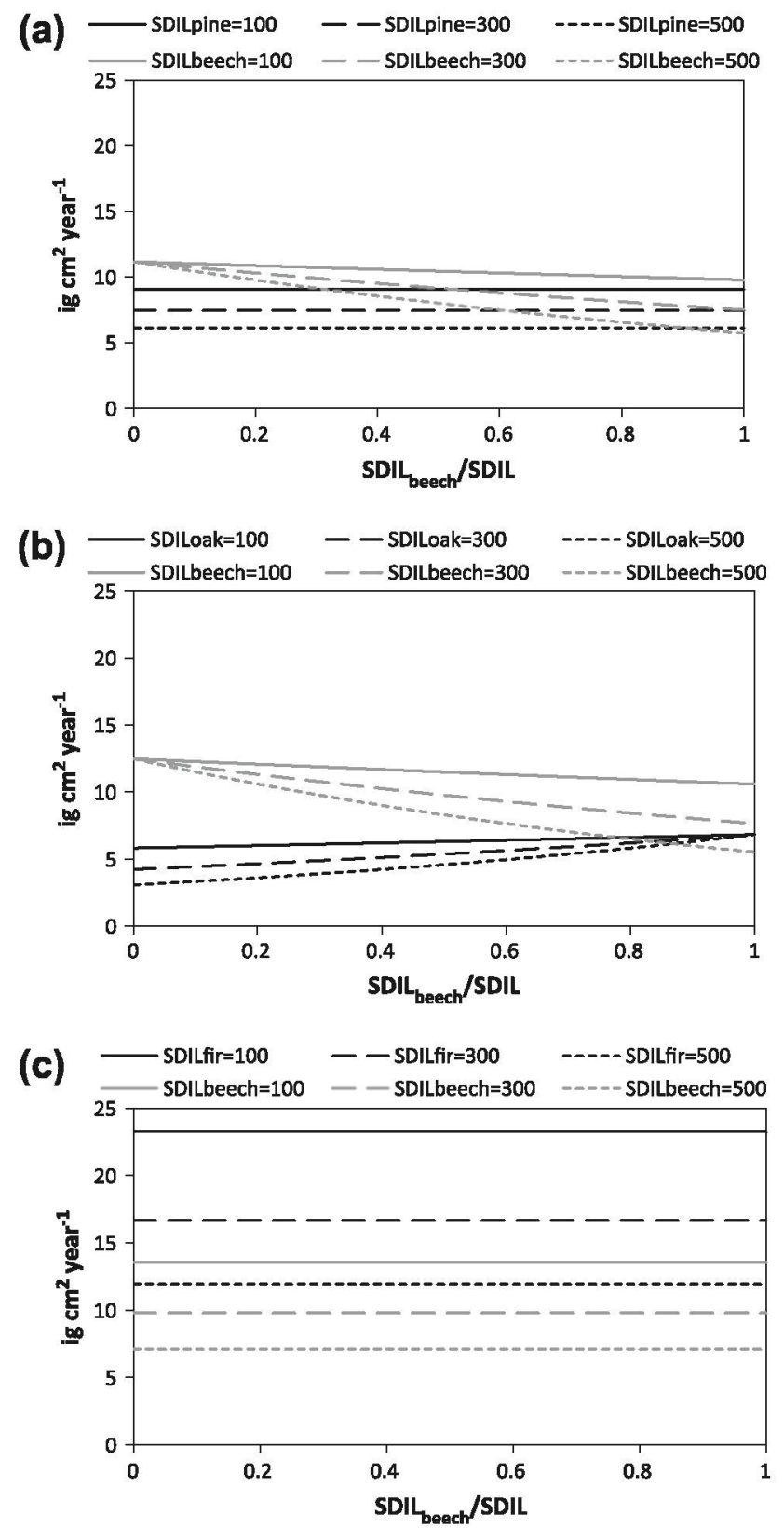

Fig. 2. Variation of tree basal area growth, growing in different admixtures (a: beech/pine; b: beech/oak; $\mathrm{c}$ : beech/fir), according to beech proportion in stand density index of large trees $\left(\mathrm{SDIL}_{\text {beech }} / \mathrm{SDIL}\right.$ ) for a tree of $25 \mathrm{~cm}$ of diameter in a stand with SDIL between 100 and 500 stem $/$ ha, SDI $=1000 \mathrm{stem} / \mathrm{ha}$ and $\mathrm{SDI}_{\text {beech }}=500$

physiological mechanisms involved in resource uptake by trees do not translate directly into an understanding of resource competition (Schwinning and Weiner, 1998). Our approach, based on the 


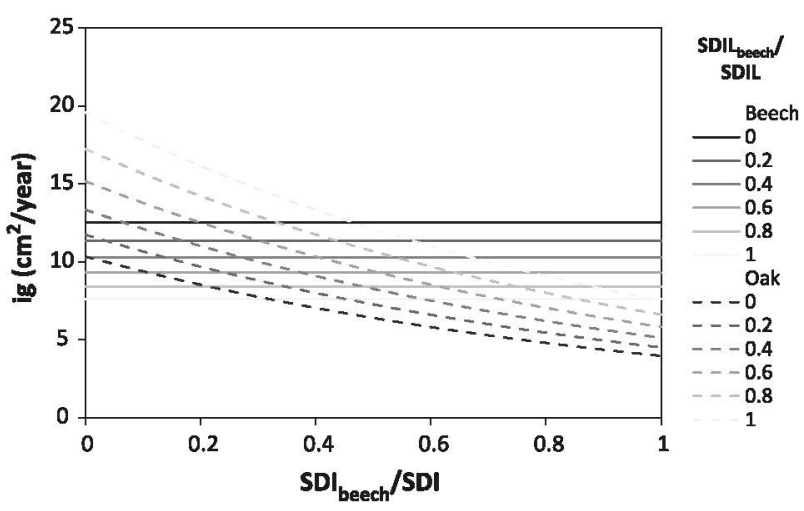

Fig. 3. Beech and oak tree basal area growth according to beech proportion in stand density index $\left(\mathrm{SDI}_{\text {beech }} / \mathrm{SDI}\right.$ ) and in stand density index of larger trees (SDIL beech $_{\text {b }}$ SDIL) for a tree of $25 \mathrm{~cm}$ of diameter with a SDIL $=300 \mathrm{stem} / \mathrm{ha}$ in a stand of $\mathrm{SDI}=600 \mathrm{stem} / \mathrm{ha}$

proxy variables of size-symmetric and size-asymmetric competition for resources among trees, distinguishing intra- and interspecific competition, provide insights into species interactions. Competition for light is usually size-asymmetric whereas competition for belowground resources tends to be size-symmetric, in accordance with the basic mechanisms of light vs. soil resource interception (Schwinning and Weiner, 1998). Hence, this approach allows us to infer whether niche complementarity occurs mainly at aboveground or belowground level.

One limitation of this approach, which is restricted by the characteristics of SNFI data, is the nature of the indices used to express tree competition status, which cannot be calculated from crown variables and spatially explicit information. However, empirical analyses found distance dependent competition indices not to be superior to distance-independent indices, especially for stationary stand structures in unthinned and undisturbed stands (Weiskittel et al., 2011). Competition indices based on crown variables have been found to outperform those based on basal area variables as surrogates for size-asymmetric competition, since differences in crown morphology among species relate closely to competition when individual tree growth is primarily controlled by light availability (Bravo et al., 2001). Therefore, the inclusion of crown-based competition indices would probably improve basal area growth models, although this lack of species-specific crown information might be partly alleviated in our approach by splitting the competition terms by species.

Another point to be noticed of our approach is related to the indices used to express competition. When using stand density index (SDI) for different species compositions it is important to consider that the maximum SDI and the allometric coefficient of this index can differ among species (Pretzsch and Biber, 2005). The use of a relative density index which considers species-specific maximum densities (Sterba, 1987; Río and Sterba, 2009; Condés et al., 2013) could avoid a confounding factor between composition and species' space occupancy on tree growth response. However, maximum SDI and the allometric exponent could also differ in mixed and pure stands as consequence of species interactions, a topic which is not still well understood. Therefore, our selected option of using SDI with the exponent proposed by Reineke (1933), might be adequate in order not to include any assumption concerning mixing effect (Dieler and Pretzsch, 2013).

The fitted basal area growth models reveal that size-asymmetric competition is generally limiting the basal area growth of the studied species more strongly than size-symmetric competition, suggesting a greater competition for aboveground resources in these mixtures. Therefore it makes sense that a competitive reduction or complementarity was mainly found in relation to aboveground resources, expressed in the size-asymmetric component of models, while negative interactions were found in size-symmetric terms. The competitive reduction detected in size-asymmetric competition in some of the models, with no significant effect of the inter-specific term, implied a reduction in the degree of asymmetry (Fig. 4) and consequently, a decrease in tree size differentiation within the stand. As relative tree size is highly correlated with the fitness of the trees (Weiner et al. 1990), it also means that there will be less differentiation in the level of fitness of the trees in a stand. Hence, when complementarity is mainly based on aboveground resources, mixtures benefit smaller trees without hampering larger ones, thus increasing the growth resilience and mechanical stability of the stand.

The admixture effect is generally more relevant in size-asymmetric competition, but the results varied among species and mixtures (Fig. 5). However, it is noteworthy that splitting competitors by species scarcely increased the predictive power of models (Table 3). For pine and oak growing with beech, inter-specific size-symmetric competition was greater than intra-specific competition, which can be interpreted as a strong 'competition' interaction between species for belowground resources. This negative effect increases with stand density, which is in accordance with the density-dependent mixing effect found in previous studies at stand level for these mixtures (Condés et al., 2013; Río et al., 2013). The fact that these studies found a positive effect of beech on pine at low stand densities and a negative effect at high densities, while our results always revealed a negative interaction at tree level might be the subject of further research.

In the case of oak, an opposite mixing effect was found between size-symmetric competition (negative) and size-asymmetric competition (non-significant involving competitive reduction), although the former seems to better explain its growth (Table 3 ). Some studies concerning belowground competition in mixed stands found that $F$. sylvatica displays greater competitive ability than oak in inter-specific interactions (Leuschner et al., 2001; Rewald and Leuschner, 2009), which might result in a negative effect of beech on oak. However, the reduction in size-asymmetric competition for both species suggests some degree of complementarity in aboveground niche occupation, probably due to their different shade tolerance and crown architecture (Ruiz de la Torre and Ceballos, 1979). These interactions involve than in this mixture

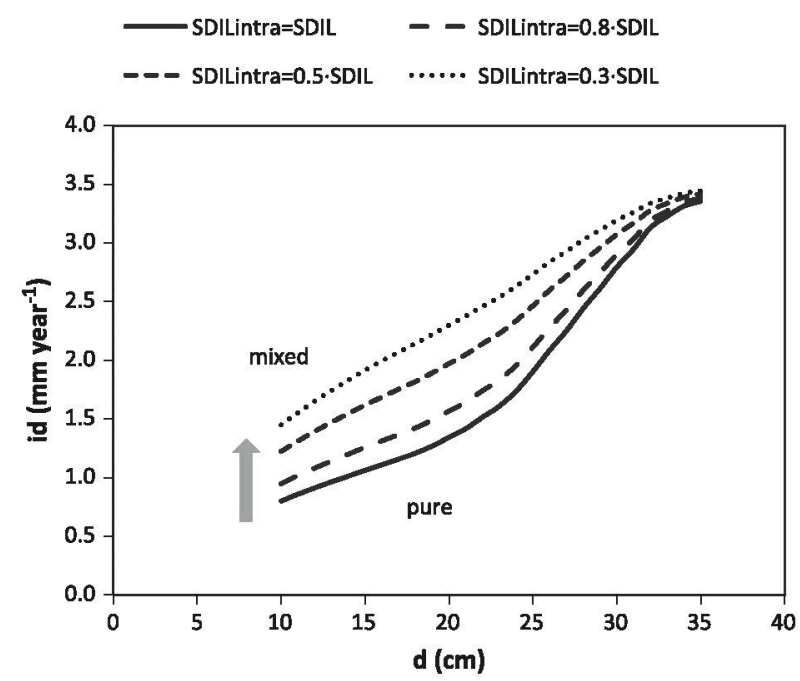

Fig. 4. Effect of species admixture on beech tree size-growth relationship. Simulations for beech growing in pure and mixed stands with different percentage of beech in larger trees: pure stand (SDIL intra $=\mathrm{SDIL}$ ), and $80 \%, 50 \%$ and $30 \%$ of beech in larger trees $\left(\right.$ SDIL $\left._{\text {intra }}=0.8 \cdot \mathrm{SDIL} ; \mathrm{SDIL}_{\mathrm{intra}}=0.5 \cdot \mathrm{SDIL} ; \mathrm{SDIL}_{\mathrm{inta}}=0.3 \cdot \mathrm{SDIL}\right)$. Simulations were based on fitted model (Table 4) assuming a normal distribution of 500 diameters with mean 24.5 and standard deviation $5 \mathrm{~cm}$. 

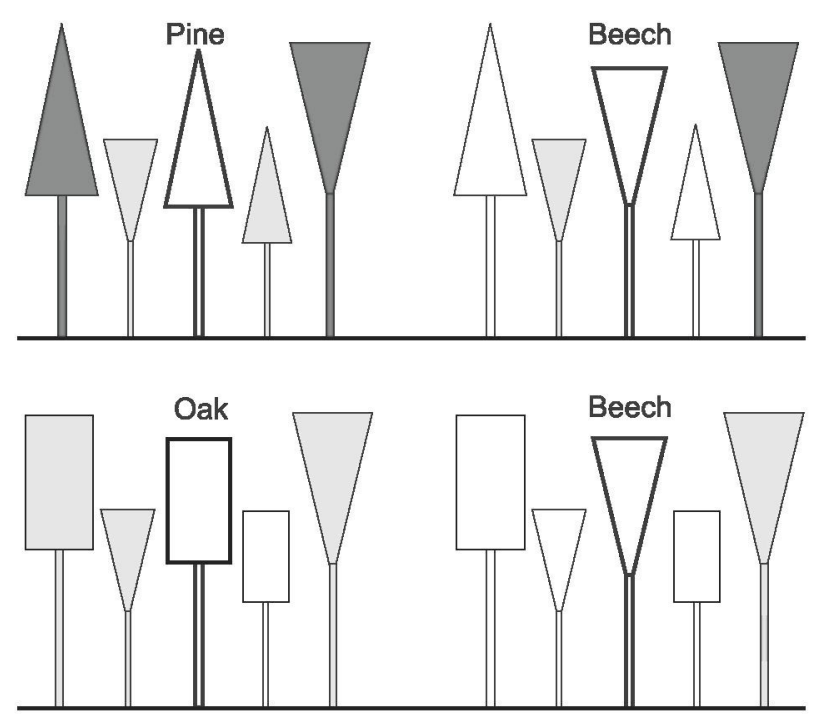

Fig. 5. Mixing effect in pine-beech (top) and oak-beech (below) stands. Target tree species, framed in black, compete differently with smaller and larger neighbors of admixed species. White-filled neighbors compete non-significantly, gray-filled slightly, and black-filled strongly with the target species.

both species show a shift in tree size-growth relationships, with a reduction in the degree of asymmetry due to a greater basal area growth of suppressed trees in mixed than in pure stands. This effect of beech on oak was lower for dominant oaks (Fig. 2b), which agrees with the findings of Hein and Dhôte (2006), who reported changes in the effect of beech admixture according to size class.

The presence of competition and competitive reduction interactions in the oak model reflects the fact that competition and complementarity/facilitation occur simultaneously (Vandermeer, 1992). Furthermore, it supports the concept that the mixing effect shifts from competition to facilitation according to ecological gradients (Pretzsch et al., 2013) and temporal variations in environmental conditions (Río et al., 2014). This concept might explain the contradictory interactions in oak-beech mixtures also found in other studies (Wiedemann, 1942, 1950; Hein and Dhôte, 2006; Pretzsch et al., 2013).

Beech clearly benefitted from the presence of pine and oak among competitors, the effect being greater in size-asymmetric competition. The low self-tolerance and high space sequestration efficiency of beech (Pretzsch and Biber, 2005; Dieler and Pretzsch, 2013) gives it an evident competitive advantage in mixed forests. The crown plasticity of beech allows it to extend its crown in mixed stands, giving a crown cross-sectional area around 1.5 times greater if surrounded by oak or pine than in pure stands (Dieler and Pretzsch, 2013). This crown extension, together with the higher light transmittance of pine and oak may be the main cause of aboveground competitive reduction. As abovementioned, the lower size-asymmetric competition for beech when mixing with pine and oak means a reduction in the degree of asymmetry, which favors the growth of smaller trees. Beech growing with pine also exhibited a competitive reduction in size-symmetric competition (related to the negative effect of beech on pine). This may be due to beech also having a greater competitive capacity for belowground resources as a result of its rooting strategy, the roots being able to increase in size and distribution through soil layers in the presence of pine (Curt and Prévosto, 2003).

Beech and fir present differences in certain traits, such as crown architecture, leaf phenology, litter composition and pattern, which could result in complementarity or facilitation, although information in this regard for this mixture is scarce. Basal area growth models for fir and beech indicated that competition was mainly size-asymmetric. Therefore, the principal growth limiting factors would be aboveground resources, so aboveground niche complementarity might be expected. The best models for both species indicated that there was no competitive reduction between them. However, the results obtained when competition was divided into intra and inter-specific terms (Table 3 ) revealed that intra-specific competition was greater than inter-specific competition, suggesting the presence of some degree of complementarity. It is important to note that the number of plots with this mixture is lower than for the other two mixtures, so these results should be contrasted with a larger data set.

Although the results indicated a lack of interaction, competition, complementarity and facilitation is a continuum, the net interaction effect varying with environmental conditions, both temporally and spatially (Pretzsch et al., 2010, 2013; Río et al., 2014), and therefore facilitation can occur in certain situations. Lebourgeois et al. (2013) found a facilitation effect of beech on fir when comparing tree-ring sensitivity to summer drought in pure and mixed stands, attributing this effect to the different strategies of water extraction by roots (Konôpka, 2001). This positive effect was only observed under the most limiting conditions, i.e. driest sites, according to the stress gradient hypothesis (Bertness and Callaway, 1994). However, size-symmetric competition linked to water resource does not seem to be relevant in our data.

The NFI data used in this study present certain characteristics which should be considered when interpreting the results. There is usually less information (and less accurate data) in the Spanish NFI regarding stands and environmental conditions as opposed to experimental data designed for a particular objective. However, the advantage of NFI's is that they provide an unbiased systematic sample of plots distributed throughout the whole range of forest types of interest (Ålvarez-González et al., 2013). One particularity of the Spanish NFI data is that they cover forests with different stocking rates, including understocked stands (Tables 1 and 2). The stand density can modify inter-specific interactions (e.g. (Amoroso and Turnblom, 2006; Condés et al., 2013) and influence the mode of competition. The degree of size-asymmetry of competition is generally greater at high densities (Schwinning and Weiner, 1998), therefore a greater level of size-asymmetric competition might have been expected in our mixtures if only fully-stocked stands had been used.

\section{Conclusions}

The growth modeling approach used in this study, which differentiates size-symmetric and size-asymmetric competition as well as intra- and inter-specific competition, is shown to be a useful tool to explore species interactions, offering valuable information to infer whether niche complementarity or facilitation mainly occur at above- or belowground level.

In the studied beech mixtures, size-asymmetric competition was revealed to be more relevant than size-symmetric competition, suggesting that light is the most limiting resource for basal area growth. Accordingly, competitive reduction was also more evident in size-asymmetric competition, as in beech-pine and beech-oak mixtures, indicating niche complementarity between species for above-ground resources. Moreover, competitive reduction in size-asymmetric competition involved greater advantages of mixing for smaller trees without hampering the larger trees. Tree size variation and multilayered stands mean a greater diversity of structure and habitats for forest plants and animals.

\section{Acknowledgements}

The authors are grateful to the European Union for funding the Cost Action EUMIXFOR FP1206 which enabled this study and to all the staff that makes possible the Spanish NFI, especially Roberto 
Vallejo, Head of the Spanish National Forest Inventory, Ministry of Agriculture, Food and Environment (MAGRAMA). The project AGL20H-29701-C02-01, funded by the Spanish Ministry of Economy and Competitiveness, partially supported this study.

\section{References}

Âlvarez-González, J., Cañellas, I., Alberdi, I., Gadow, K., Ruiz-González, A., 2013. National forest inventory and forest observational studies in Spain: applications to forest modeling. For. Ecol. Manage., <http://dx.doi.org/10.1016/ j. foreco.2013.09.007>.

Amoroso, M.M., Turnblom, E.C., 2006. Comparing productivity of pure and mixed Douglas-fir and western hemlock plantations in the Pacific Northwest. Can. J. For. Res. 36, 1484-1496.

Bertness, M.D., Callaway, R., 1994. Positive interactions in communities. Trends Ecol. Evol. 9, 191-193.

Biondi, F., 1999. Comparing tree-ring chronologies and repeated timber inventories as forest monitoring tools. Ecol. Appl. 9, 216-227.

Bravo, F., Hann, D.W., Maguire, D.A., 2001. Impact of competitor species composition on predicting diameter growth and survival rates of Douglas-fir trees in southwestern Oregon. Can. J. For. Res. 31, 2237-2247.

Canham, C.D., LePage, P.T., Coates, K.D., 2004. A neighborhood analysis of canopy tree competition: effects of shading versus crowding. Can. J. For. Res. 34, 778787.

Condés, S., Del Rio, M., Sterba, H., 2013. Mixing effect on volume growth of Fagus sylvatica and Pinus sylvestris is modulated by stand density. For. Ecol. Manage. $292,86-95$.

Curt, T., Prévosto, B., 2003. Rooting Strategy of Naturally Regenerated Beech in Silver Birch and Scots Pine Woodlands. Roots: The Dynamic Interface between Plants and the Earth. Springer, pp. 265-279.

Dieler, J., Pretzsch, H., 2013. Morphological plasticity of European beech (Fagus sylvatica L.) in pure and mixed-species stands. For. Ecol. Manage. 295, 97-108.

Hein, S., Dhôte, J.F., 2006. Effect of species composition, stand density and site index on the basal area increment of oak trees (Ouercus sp.) in mixed stands with beech (Fagus sylvatica L.) in northern France. Ann. For. Sci. 63, 457-467.

Hugershoff, R., 1936. Die mathematischen Hilfsmittel der Kulturingenieurs und Biologen. Vol 2, Herleitung von gesetzmäßigen Zusammenhängen als Manuskript veröffentlicht. Dresden.

Konôpka, B., 2001. Analysis of interspecific differences in tree toot system cardinality. J. For. Sci. 47, 366-372.

Lebourgeois, F., Gomez, N., Pinto, P., Mérian, P., 2013. Mixed stands reduce Abies alba tree-ring sensitivity to summer drought in the Vosges mountains, western Europe. For. Ecol. Manage. 303, 61-71.

leuschner, C., Hertel, D., Coners, H., Büttner, V., 2001. Root competition between beech and oak: a hypothesis. Oecologia 126, 276-284.

Milios, E., 2004. The influence of stand development process on the height and volume growth of dominant Fagus sylvatica L. s.l. trees in the central Rhodope Mountains of north-eastern Greece. Forestry 77, 17.

Perot, T., Picard, N., 2012. Mixture enhances productivity in a two-species forest: evidence from a modeling approach. Ecol. Res. 27, 83-94.

Perot, T., Goreaud, F., Ginisty, C., Dhôte, J.F., 2010. A model bridging distancedependent and distance-independent tree models to simulate the growth of mixed forests. Ann. For. Sci., 67.
Pretzsch, H., Biber, P., 2005. A re-evaluation of Reineke's rule and stand density index. For. Sci. 51, 304-320.

Pretzsch, H., Biber, P., 2010. Size-symmetric versus size-asymmetric competition and growth partitioning among trees in forest stands along an ecological gradient in central Europe. Can. J. For. Res. 40, 370-384.

Pretzsch, H., Schütze, G., 2009. Transgressive overyielding in mixed compared with pure stands of Norway spruce and European beech in Central Europe: evidence on stand level and explanation on individual tree level. Eur. J. For. Res. 128, $183-204$.

Pretzsch, H., Block, J., Dieler, J., Dong, P.H., Kohnle, U., Nagel, J., Spellmann, H., Zingg, A., 2010. Comparison between the productivity of pure and mixed stands of Norway spruce and European beech along an ecological gradient. Ann. For. Sci. $67,1-12$.

Pretzsch, H., Bielak, K., Block, I., Bruchwald, A., Dieler, J., Ehrhart, H.-P., Kohnle, U., Nagel, J., Spellmann, H., Zasada, M., 2013. Productivity of mixed versus pure stands of oak (Quercus petraea (MATT.) LIEBL. and Quercus robur L.) and European beech (Fagus sylvatica L.) along an ecological gradient. Eur. J. Forest Res. 132, 263-280.

R, D.C.T., 2011. R: A Language and Environment for Statistical Computing. R Foundation for Statistical Computing, Vienna, Austria.

Reineke, L.H., 1933. Perfecting a stand-density index for even-aged forests. J. Agric. Res. 46, 627-638.

Rewald, B., Leuschner, C., 2009. Belowground competition in a broad-leaved temperate mixed forest: pattern analysis and experiments in a four-species stand. Eur. J. For. Res. 128, 387-398.

Rio, M. Sterba, H., 2009. Comparing volume growth in pure and mixed stands of Pinus sylvestris and Quercus pyrenaica. Ann. For. Sci. 66 (5), 502-502.

Río, M., Montero, G., Bravo, F., 2001. Analysis of diameter-density relationships and self-thinning in non-thinned even-aged Scots pine stands. For. Ecol. Manage. $142,79-87$.

Río, M., Condés, S., Sterba, H., 2013. Productividad en masas mixtas vs. masas puras: influencia de la espesura en la interacción entre especies. In: Actas $6^{\circ}$ Congreso Forestal Español CD-Rom. 6CFE01-121:13. Sociedad Española de Ciencias Forestales, Pontevedra.

Río, M., Schütze, G., Pretzsch, H., 2014. Temporal variation of competition and facilitation in mixed species forests in Central Europe. Plant Biol. 16, 166.

Ruiz de la Torre, J., Ceballos, L., 1979. Arboles y arbustos de la España peninsular Escuela Técnica Superior de Ingenieros de Montes.

Schwinning, S., Weiner, J., 1998. Mechanisms determining the degree of size asymmetry in competition among plants. Oecologia 113, 447-455.

Sterba, H., 1987. Estimating potential density from thinning experiments and inventory data. For. Sci. 33 (4), 1022-1034.

Vandermeer, J.H., 1992. The Ecology of Intercropping. Cambridge University Press.

Weiner, J., Berntson, G.M., Thomas, S.C., 1990. Competition and growth form in a woodland annual. J. Ecol., 459-469.

Weiskittel, A.R., Hann, D.W., Kershaw Jr, J.A., Vanclay, J.K., 2011. Forest growth and yield modeling. John Wiley \& Sons.

Wichmann, L., 2001. Annual variations in competition symmetry in even-aged sitka spruce. Ann. Bot. 88, 145-151.

Wiedemann, E., 1942. Der Eichenbestand mit Buchenunterwuchs. Zeitschrift für Forst-und Jagdwesen 74, 305-335.

Wiedemann, E., 1950. Ertragskundliche und waldbauliche Grundlagen der Forstwirtschaft. Sauerländer.

Wykoff, W.R., 1990. A basal area increment model for individual conifers in the northern Rocky Mountains. For. Sci. 36, 1077-1104. 